\title{
RANCANG BANGUN APLIKASI JADWAL KAJIAN ISLAM BERBASIS ANDROID PADA PERUSAHAAN SD TECHNOLOGIES
}

\author{
Ryan Zulham Ramadhani \\ Program Studi Informatika \\ Fakultas Teknik Universitas Muhammadiyah Tangerang \\ Jl. Perintis Kemerdekaan 1/33 Cikokol Kota Tangerang \\ ryanzulham@gmail.com
}

\begin{abstract}
SD Technologies is a company that uses Artificial Intelligence technology by providing Virtual Assistant applications for individual and corporate business needs. SD Tecnologies companies need data from the Islamic study schedule application for the need for additional content in the Lenna application. This application aims to facilitate the Islamic community in finding the schedule of Islamic studies. Islamic studies are directed at Islamic studies that lead to three things: 1) Islam that leads to submission or surrender, 2) Islam can be interpreted to lead to the salvation of the world and the hereafter, because the teachings of Islam essentially guide people to do good and stay away from all prohibitions, 3) Islam leads to peace.To overcome the problem of the schedule of Islamic studies at SD Technologies, a new system is needed that can present information. With the system development method using the System Development Life Cycle (SDLC) with extreme progamming models. And by using data collection methods using methods of observation, interviews and literature studies. While the design method in this study with Unified Modeling Language (UML), programming used using Android, the creation of an API using native PHP and a database using MySQL. The results of this study are in the form of an Android-based Islamic study schedule application that will provide study schedule information to Islamic communities wherever they wish to study.
\end{abstract}

Keywords: Islamic Studies, Study Schedule, Android, PHP Native, Unified Modeling Language (UML), MySQL.

\section{PENDAHULUAN}

Seiring dengan kemajuan teknologi, tingkat kebutuhan manusia akan teknologi dalam penggunaan sehari-hari semakin tinggi, salah satu contoh perkembangan teknologi yaitu sistem informasi yang terkomputerisasi. Sistem informasi mempunyai peran yang sangat penting karena berkaitan dengan pengolahan data yang digunakan diberbagai perusahaan dan instansi untuk mempermudah pekerjaa.

Saat ini telepon genggam (handphone) yang sedianya sebagai alat komunikasi sudah memiliki kelebihan yang cukup banyak dari fungsi dasarnya. Hal ini bisa terjadi tak lepas karena adanya sistem operasi pada telepon genggam yang mendukung untuk menjadi telepon pintar 
(smartphone). Salah satu sistem operasi yang digunakan pada telepon pintar sekarang ini adalah Android. Sudah banyak aplikasi menggunakan android, sehingga lebih mudah digunakan oleh siapa saja, kapan saja dan dimana saja.

Perusahaan SD Technologies merupakan perusahaan yang menggunakan teknologi Artificial Intelligence dengan menyediakan aplikasi Virtual Assistant untuk keperluan bisnis individu dan perusahaan. Perusahaan SD Tecnologies membutuhkan data dari aplikasi jadwal kajian islam untuk kebutuhan penambahan konten di aplikasi lenna. Aplikasi ini bertujuan untuk memudahkan para masyarakat islam dalam mencari jadwal kajian islam.

\section{TINJAUAN PUSTAKA}

\section{A. Android}

Android adalah sistem operasi untuk telpon seluler/handphone yang berbasis linux. Android menyediakan platform terbuka bagi para pengembang untuk menciptakan aplikasi mereka sendiri agar bisa digunakan berbagai macam peranti bergerak. Pada awalnya, Android.Inc dibeli oleh Google.Inc, tapi untuk mengembangkan android dibentuklah sebuah tim kerja dengan nama Open Handset Alliance, yang terdiri dari 34 perusahaan piranti keras, piranti lunak dan telekomunikas. (Mulyanto, Sistem Informasi Konsep dan Aplikasinya, 2009).

\section{B. Versi android}

Android dibuat dengan basis kernel linux yang telah dimodifikasi, dan untuk setiap release-nya diberi kode nama berdasarkan nama hidangan makanan ringan.

Meskipun tidak direkomendasikan, kinerja dan fitur android dapat lebih ditingkatkan dengan melakukan root. Fitur seperti Wireless Tethering, Wired tethering, uninstall crapware, overlock processor dan install custom flash ROM dapat dilakukan pada android yang sudah di root. (Nico, 2015)

Berikut merupakan versi yang sudah dikeluarkan oleh android :

1. Eclair (2.0/2.1)

Versi android awal yang mulai dipakai oleh banyak smartphone, fitur utama Eclair yaitu perubahan total struktur dan tampilan user interface dan merupakan versi Android yang pertama kali mendukung format HTML 5.

2. Froyo/Frozen Yogurt (2.2)

Android 2.2 dirilis dengan 20 fitur baru, antara lain peningkatan kecepatan, fitur Wi-Fi hotspot tethering dan dukungan terhadap Adobe Flash.

3. Gingerbread (2.3)

Perubahan utama diversi 2.3 ini termasuk update UI, peningkatan fitur soft keyboard dan copy/paste, power management dan support Near Field Communication (NFC).

4. Honeycomb (3.0, 3.1 dan 3.2)

Merupakan versi android yang ditujukan untuk gadget/device dengan layar besar seperti Tablet Pc. Fitur baru Honeycomb yaitu dukungan terhadap processor multicore dan grafis dengan hardware acceleration.

5. Ice Cream Sandwich (4.0)

Diumumkan pada 10 Mei 2011 diajang Google I/O Developer Conference di San Fransisco, Amerika Serikat.

6. Jelly Bean (4.1, 4.2 dan 4.3)

Jelly Bean dirancang untuk mengoptimalkan kemampuan System on Chip (SoC) pada tiap-tiap ponsel. Terdapat optimalisasi pada processor 
sehingga meningkatkan responsifitas ponsel.

7. Kitkat

Android ini memfokuskan pada manajemen memory sehingga device low-end yang memiliki memory rendah tetap dapat berjalan lancar dan minim lag.

8. Lollipop (5.0)

Perubahan desain user interface menggunakan material design, perubahan runtime dari dalvik menjadi Android Runtime (ART) dan hadirnya fitur penghemat daya baterai yaitu Project Volta.

9. Marshmallow (6.0)

Perubahan permission (izin aplikasi), manajemen daya baterai bernama Doze, mendukung secara native sensor pemindai sidik jari, dan mendukung pengisian jenis baru atau USB Type-C.

10. Nougat (7.0)

Kehadiran split screen multi-window mode, seamless update, penghemat baterai doze, data saver penghemat kuota internet, penambahan emoji baru, dll.

\section{Unified Modeling Language (UML)}

"Unified Modeling Languange merupakan bahasa visual untuk pemodelan dan komunikasi mengenai sebuah sistem dengan menggunakan diagram dan teksteks pendukung". Unifield Modeling Language menyediakan bahasa pemodelan visual yang memungkinkan bagi pengembang sistem untuk membuat cetak biru atau visi mereka dalam bentuk yang baku, mudah dimengerti serta dilengkapi dengan mekanisme yang efektif untuk berbagi (sharing) dan mengkomunikasikan rancangan mereka dengan yang lain (Sora, 2015).

\section{Kualifikasi Diagram Unified Modeling Language (UML)}

1. Use case Diagram

Use case diagram yaitu salah satu jenis diagram pada UML yang menggambarkan interaksi antara sistem dan actor, use case diagram juga dapat mendeskripsikan tipe interaksi antara si pemakai sistem dengan sistemnya (Sora, 2015).

2. Statechart Diagram

Statechart diagram memodelkan tingkah laku objek khusus yang dinamis. Diagram ini menggambarkan siklus hidup objek sebagai berbagai keadaan yang dapat diasumsikan oleh objek dan event (kejadian) yang menyebabkan objek dapat beralih dari satu state ke state lain (Sugiarti, 2013: 38).

3. Activity Diagram

Activity diagram atau diagram aktivitas yaitu salah satu jenis diagram UML yang dapat memodelkan proses-proses apa saja yang terjadi pada sistem (Sora, 2015).

4. Sequence diagram

Sequence diagram yaitu salah satu jenis diagram pada UML yang menjelaskan interaksi objek yang berdasarkan urutan waktu. Sequence diagram juga dapat menggambarkan urutan atau tahapan yang harus dilakukan untuk dapat menghasilkan sesuatu seperti pada use case diagram (Sora, 2015).

5. Class Diagram

Class diagram yaitu salah satu jenis diagram pada UML yang digunakan untuk menampilkan kelas-kelas maupun paket-paket yang ada pada suatu sistem yang nantinya akan digunakan. Jadi diagram ini dapat memberikan sebuah gambaran mengenai sistem maupun relasi- 
relasi yang terdapat pada sistem tersebut (Sora, 2015).

\section{E. Model Extreme Programming}

Dalam rekayasa perangkat lunak, konsep SDLC mendasari berbagai jenis metodologi pengembangan perangkat lunak. Metodologi-metodologi ini membentuk suatu kerangka kerja untuk perencanaan dan pengendalian pembuatan sistem informasi, yaitu proses pengembangan perangkat lunak. Beberapa proses pengembangan sistem dengan SDLC adalah: Extreme Programming, Waterfall, Prototyping, Incremental, Spiral, dan lainlain.

Extreme Programming adalah sebuah pendekatan atau model pengembangan perangkat lunak yang mencoba menyederhanakan berbagai tahapan dalam proses pengembangan tersebut sehingga menjadi lebih adaptif dan fleksibel. XP bukan hanya berfokus pada coding tetapi meliputi seluruh area pengembangan perangkat lunak. XP mengambil pendekatan 'ekstrim' dalam iterative development.

Berikut fase - fase dalam model Extreme Programming menurut referensi Pressman :

1. Planning

2. Design

3. Coding

4. Testing

\section{F. Kelebihan dan Kekurangan Extreme Programming (XP)}

1. Kelebihan :

a. Meningkatkan kepuasan kepada klien

b. Pembangunan system dibuat lebih cepat

c. Menjalin komunikasi yang baik dengan client. d. Meningkatkan komunikasi dan sifat saling menghargai antar developer.

2. Kekurangan :

a. User story kemungkinan besar tidak lengkap sehingga Developer harus selalu siap dengan perubahan karena perubahan akan selalu diterima.

b. Tidak bisa membuat kode yang detail di awal (prinsip simplicity dan juga anjuran untuk melakukan apa yang diperlukan hari itu juga).

c. XP tidak memiliki dokumentasi formal yang dibuat selama pengembangan. Satu-satunya dokumentasi adalah dokumentasi awal yang dilakukan oleh user.

\section{METODOLOGI PENELITIAN}

\section{A. Metode Pengumpulan Data}

1. Studi pustaka

Penulismengumpulkan data - data yang dapat diperoleh dari pencarian referensi - referensi dari internet dengan website yang dapat dipercaya kebenarannya, buku buku atau jurnal - jurnal ilmiah yang berhubungan dengan rancang bangun aplikasi jadwal kajian islam berbasis android pada Perusahaan SD Technologies, dan tetap memperhatikan kebenaran informasinya.

\section{Penelitian lapangan}

Penelitian yang dimaksud adalah penelitian yang dilaksanakan dengan melihat proses kegiatan dilapangan guna untuk membuat gambaran mengenai kejadian atau situasi yang ada dilapangan. Hal ini sangat diperlukan guna memperoleh gambaran secara sistematis, cermat dan akurat mengenai fakta, sifat dan 
hubungan antara keadaan yang diteliti.

Dalam penelitian lapangan, penulis menggunakan metode observasi dalam pengumpulan datanya. Observasi merupakan salah satu teknik pengumpulan data yang tidak hanya mengukur sikap dari responden (wawancara) namun juga dapat digunakan untuk merekam berbagai fenomena yang terjadi (situasi, kondisi). Teknik ini digunakan bila penelitian ditujukan untuk mempelajari perilaku manusia, proses kerja, gejala-gejala alam dan dilakukan pada responden yang tidak terlalu besar.

Adapun cara yang dilakukan untuk mengadakan penelitian lapangan dengan menggunakan metode observasi adalah sebagai berikut :

a. Observasi langsung

Guna mengumpulkan informasi mengenai kebutuhan sistem penulis melakukan pengumpulan data dengan cara obeservasi langsung di tempat penelitian yaitu di Perusahaan SD Technologies dan majelis Al-Bahjah Tangerang. Penulis melakukan observasi untuk melihat proses penjadwalan kajian islam.

b. Wawancara

Wawancara merupakan salah satu metode pengumpulan data yang dapat digambarkan sebagai sebuah interaksi yang melibatkan antara pewawancara (orang yang bertanya) dengan yang diwawancarai (orang yang memberikan jawaban atas pertanyaan), dengan maksud mendapatkan informasi yang sah dan dapat dipercaya.
Untuk melengkapi data yang sudah ada, penulis melakukan wawancara atau tanya jawab kepada Bapak Ryan di Perusahaan SD Technologies dan Bapak ustadz Abdul Roman selaku panitia majelis Al-Bahjah Tangerang .

Dalam wawancara yang dilakukan penulis, penulis mengumpulkan beberapa data dan informasi yang berhubungan dengan rancang bangun aplikasi Jadwal Kajian Islam.

\section{B. Metode Pengembangan Sistem}

Metode dalam pengembangan sistem ini menggunakan System Development Life Cycle (SDLC) dengan model proses Extreme Programming. Menurut Pressman (2010) tahapan dalam model proses Extreme Programming sebagai berikut:

\section{a. Planning}

Dalam tahap ini dikumpulkan kebutuhan awal user atau dalam XP disebut user stories. Hal ini dibutuhkan agar pengembang mengerti bisnis konten, kebutuhan output sistem, dan fitur utama dari software yang dikembangkan. Tahapan ini untuk menganalisa kebutuhan dari sistem tersebut untuk dapat digunakan sesuai dengan user requirement atau user stories., identifikasi masalah yang sedang terjadi di Perusahaan SD Technologies.

b. Design

Tahap ini pemodelan menggunakan UML sebagai alat bantu untuk menggambarkan perancangan sistem yang akan dibuat. Pada tahap ini, proses ini 
digunakan untuk mengubah kebutuhan - kebutuhan calon pengguna yaitu admin (operator sekolah) dan user (wali murid) menjadi representasi kedalam sistem sebelum pengkodean dimulai. Desain perangkat lunak yang digunakan dalam tahap ini adalah UML (UnifiedModellingLanguage) yang terdiri dari Usecase Diagram, ActivityDiafram, Sequence Diagram dan Class Diagram.

c. Coding

Proses melakukan coding system (pengkodean perangkat lunak)oleh Programmer/Software Engineer sesuai dengan planning dan design yang telah dibuat sebelumnya.

d. Testing

Tahap ini akan menggunakan unit test yang sebelumnya telah dibuat. Karena pembuatan dari unit test adalah pendekatan utama dari XP. Dalam melakukan pengujian, penulis menggunakan teknik pengujian yaitu pengujian black box. Pada tahap pengujian black box, dilakukan pengujian setiap unit test, maksudnya melakukan pengujian integrasi antara input dan hasil output yang sesuai semestinya terjadi.

\section{HASIL DAN PEMBAHASAN}

Proses analisi sistem mendeskripsikan apa yang harus dilakukan oleh sistem untuk memenuhi kebutuhan informasi pengguna. Analisis sistem akan menjawab pertanyaan apa yang akan dikerjakan oleh sistem, siapa yang akan menggunakan sistem, dan dimana serta kapan sistem tersebut akan digunakan. Kegiatan analisis sistem yang berjalan dilakukan dengan pendekatan analisis berorientasi objek, dimaksudkan untuk menitik beratkan kepada fungsionalitas sistem yang berjalan. Selanjutnya dari hasil analisis akan divisualisasi dan didokumentasikan dengan Unified Modeling Language (UML) melalui Use Case Diagram, Activity Diagram, Sequence Diagram dan Class Diagram dengan pertimbangan diagram tersebut dianggap mewakili secara keseluruhan sistem yang berjalan yang dapat dimengerti oleh pengguna.

A. Masalah yang Ada Sebelum Dikembangkan Sistem

Setelah penulis mempelajari dan menganalisa sistem yang ada, adapun permasalahan pokok mengenai jadwal kajian yang berjalan yaitu:

1. Informasi Jadwal kajian sebelumnya hanya melalui grup whatsapp dan grup facebook.

2. Proses penginputan Jadwal Kajin dilakukan di grup whatsapp dan grup facebook.

\section{B. Fungsi dan Kegunaan Sistem \\ 1. Fungsi Sistem}

Adapun fungsi aplikasi Jadwal Kajian Islam yaitu:

a. Database Aplikasi Jadwal Kajian Islam menggunakan MySql

Berfungsi sebagai penyimpanan data jadwal kajian islam.

b. Menu Login pada Aplikasi Jadwal Kajian Islam

Menu Login hanya untuk panitia penyelenggara kajian.

c. Menu Input Kajian pada Aplikasi Jadwal Kajian Islam

Merupakan menu yang digunakan menginput semua data yang dibutukan dalam membuat jadwal kajian. 


\section{Kegunaan Sistem} Adapun kegunaan Aplikasi Jadwal Kajian Islam yaitu:

a. Mempermudah panitia dalam penyampaian jadwal kajian.

b. Mempermudah para masyarakat islam dalam mencari jadwal kajian islam.

\section{Penggambaran Sistem yang Diusulkan}

\section{Use Case Diagram}

Use Case Diagram digunakan untuk menjelaskan apa yang akan dilakukan oleh sistem serta aktor-aktor yang akan berhubungan dengan proses-proses yang ada di sistem yang di usulkan.

Sistem pada Use Case ini memiliki 2 actor, yaitu:

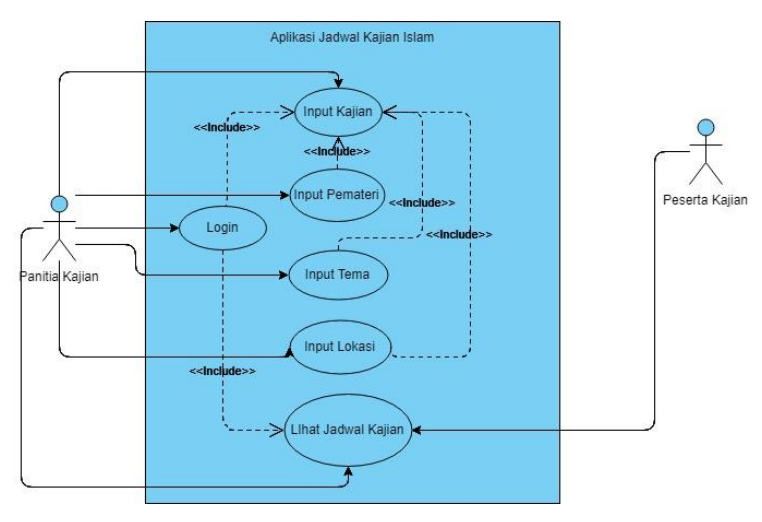

Gambar 1. Use Case Diagram Usulan

\section{Activity Diagram}

Activity diagram digunakan untuk kegiatan-kegiatan yang ada dalam suatu sistem. Berikut ini activity diagram yang diajukan : a. Activity Diagram Input Kajian

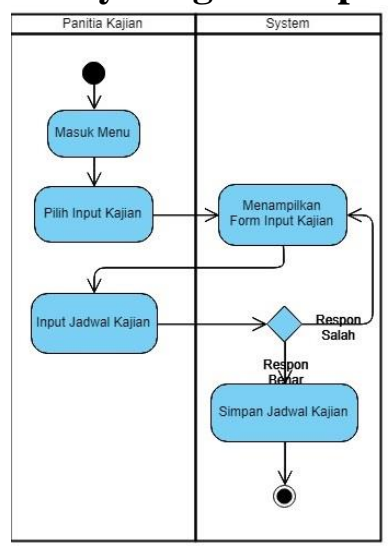

Gambar 2. Activity Diagram Input Kajian

b. Activity Diagram Lihat Kajian

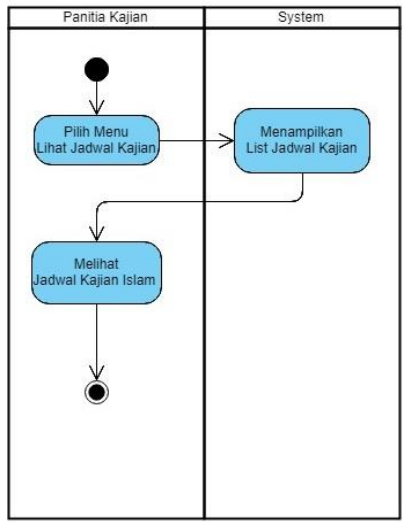

Gambar 3. Activity Diagram Lihat Kajian

3. Perancangan Sequence Diagram a. Sequence Diagram Input Kajian

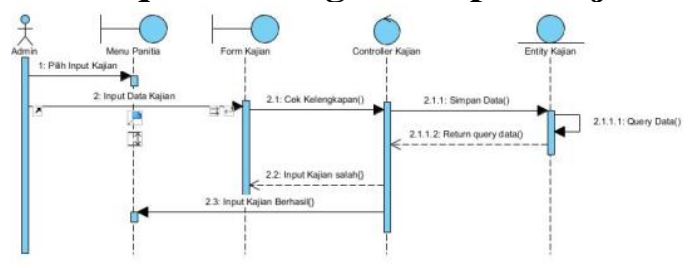

Gambar 4. Sequence Diagram Input Kajian

b. Sequence Diagram Lihat Kajian

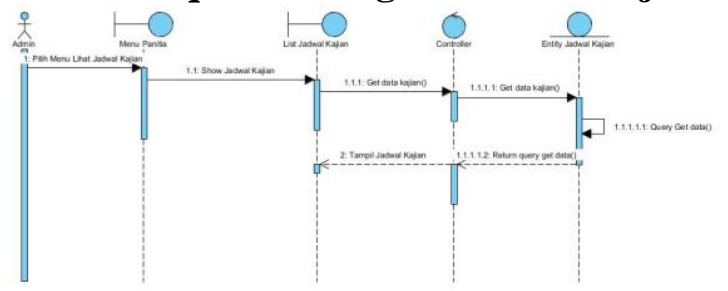

Gambar 5. Sequence Diagram Lihat Kajian 
4. Perancangan Class Diagram

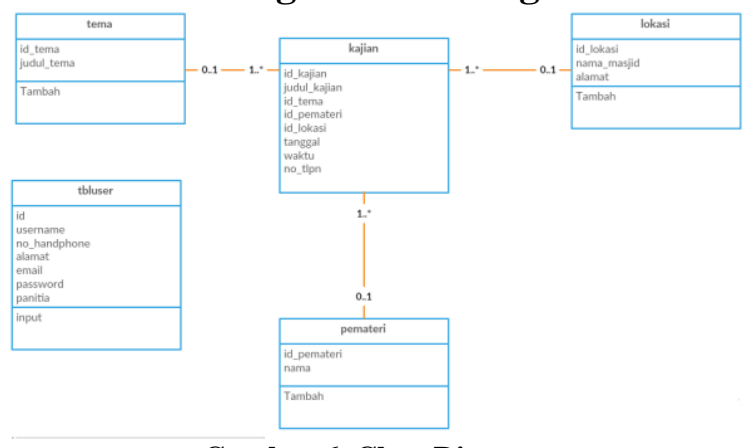

Gambar 6. Class Diagram

\section{Implementasi}

a. Tampilan Menu Utama

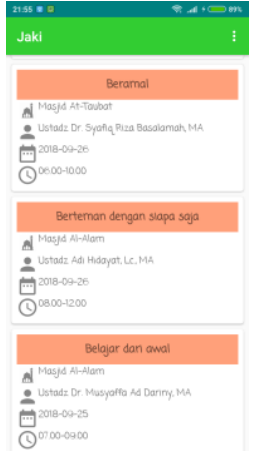

Gambar 7. Tampilan Menu Utama

\section{b. Tampilan Detail Kajian}
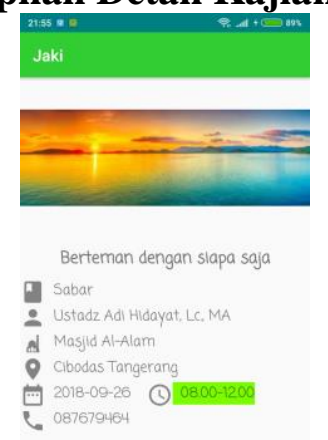

Gambar 8. Tampilan Detail Kajian c. Tampilan Login

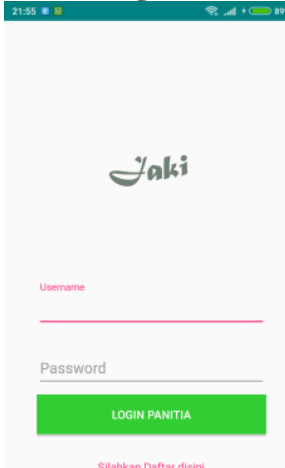

Gambar 9. Tampilan Login

d. Tampilan Register

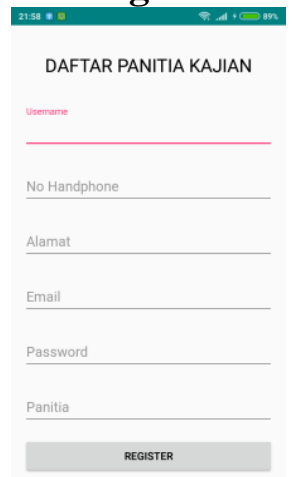

Gambar 10. Tampilan Register

e. Tampilan Menu Panitia Kajian

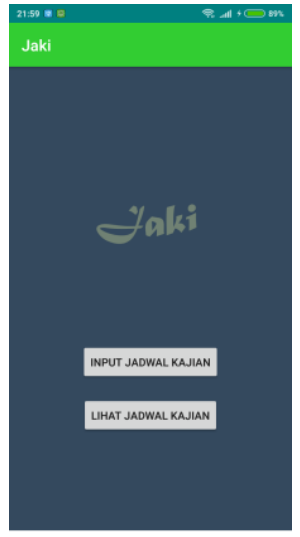

Gambar 11. Tampilan Menu Panitia Kajian 


\section{f. Tampilan Input Kajian}

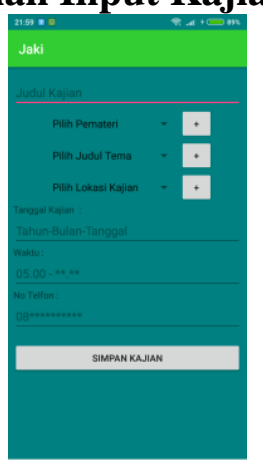

Gambar 12. Tampilan Input Kajian

\section{KESIMPULAN}

Proses pembuatan aplikasi jadwal kajian islam menggunakan metode extreme progamming, dengan beberapa tahapan yaitu observasi, perencanaan, desain, coding dan pengujian lalu tahap akhir adalah implementasi aplikasi kepada user.

Pengujian aplikasi menggunakan metode pengujian Black Box yang dilakukan kepada pengguna aplikasi.

Penggambaran sistem menggunakan Unified Modeling Language dengan menampilkan beberapa diagram seperti use case diagram, activity diagram, sequence diagram dan class diagram.

\section{REFERENSI}

[1] Developer Android. (2017, 11 05). https://developer.android.com/studi o/intro/index.html?hl=id. Diambil kembali dari https://developer.android.com/studi o/intro/index.html?hl=id: https://developer.android.com/studi o/intro/index.html?hl=id
[2] Mulyanto, A. (2009). Dalam Sistem Informasi Konsep dan Aplikasinya. Yogyakarta: Pustaka Pelajar.

[3] Sora. (2015, September 24). Dipetik 27 Juli, 2018, dari Pengertianku: http://www.pengertianku.net/2015/0 9/pengertian-uml-dan-jenisjenisnya-serta-contohdiagramnya.html 